\title{
UNOSUAL MICROSTRUCTURES FROM THE GIVETIAN HAMILTON GROUP OF PENNSYIVANIA AND NEW YORK
}

\author{
by James 0 . Brown
}

Dept. of Geology, Brooklyn College and the Graduate school of CUNY, Brooklyn, New York 11210 and JMZ Geology*, 43 Emery Avenue, Flemington, New Jersey 08822 *mailing address

\begin{abstract}
The processing of siliciclastic rocks, mainly shale, noncalcareous mudstone, and siltstone, from the upper part (Montebello and unnamed members) of the Mahantango Formation (Hamilton Group) in central Pennsylvania and southeastern New York has produced several unusual types of microstructures. These microspecimens were collected from non-calcareous siliciclastics stratigraphically between the Centerfield and Tully Formations and their equivalents. These specimens offer a unique opportunity to evaluate biostratigraphic and paleoecologic conditions of section rarely studied for microfossils.
\end{abstract}

Specimens range from approximately 0.1 to $1.0 \mathrm{~mm}$ in size. One group is believed to be the blastomere(s) of arthropods. These specimens are typically black in color, ovoid to spherical in shape with a smooth to nodose surface. A second group may be the limonitic replacement of either a "soft-bodied" sponge or coelenterate. These orange-brown structures vary from a curved two-layer cone, to a stemmed cup, to a rectangular "tub", to a flat discoidal shape. A third group is believed to be weathered, mainly heteromorphic, white, agglutinated foraminifera. Finally, a single sample from the Girty's Notch section north of Harrisburg, Pennsylvania yields abundant glassy, pale green, heteromorphic, "spicule-like" microstructures. This material may not be organic, but rather shards of volcanic glass - some of which appears to have cooled around microfossils. Other identified - to at least upper taxonomic levels - microfossils include ostracodes, juvenile brachiopods, conodont fragments and vertebrate remains.

By presenting specimens collected to date at the NAPC, I hope to establish the taxonomic affinities of these microstructures. In one or two cases, I also hope to obtain feedback on whether further collection of certain of these structures would further knowledge within the paleontological community on the paleoecology and biostratigraphy of the upper Hamilton Group or be little more than a curious waste of time... 